\title{
ДЕЯКІ АСПЕКТИ ВИЗНАННЯ РІШЕНЬ ЗАГАЛЬНИХ ЗБОРІВ ГОСПОДАРСЬКИХ ТОВАРИСТВ НЕДІЙСНИМИ
}

\author{
КАЗАКОВА Крістіна Іванівна - здобувач вищої освіти СО «Магістр", \\ юридичний факультет Донецького національного університеут імені Василя \\ Cтуса
}

УДК 346.2:347.19:347.72

DOI 10.32782/LAW.UA.2021.2.23

В данной статье исследованъ проблемнъле вопросъ применения такого способа зашиты корпоративньхх прав, как признание недействительньлми решений общего собрания хозяйственного общества. Обоснована необходимость установки отдельного четко20 перечня оснований для признания общего собрания недействительнъим. Въяялень устаревшие положения Постановления Пленума Висшего хозяйственного суда Украинъ «O некоторых вопросах практики разрешения споров, возникаюших из корпоративных правоотношений» от 25.02.2016 № 4 в связи с принятием нового Закона Украинъ «Об обществах с ограниченной и дополнительной ответственностью» и после внесения изменений в Закон Украинъ «Об акиионернъих обществах». Определен перечень оснований признания недействительнълми решений общего собрания. Уточнен круг субгектов, имеюших право на обжалование решений общего собрания; аргументировано установление для участников общества с ограниченной ответственностью такого же срока обжалования решения общего собрания, как и для акционеров акиионерного общества - в три месяиа с датъ его принятия.

Ключевъе слова: общее собрание общества; решение общего собрания общества; обжалование решений общего собрания общества; основания признания решений общего собрания недействительнылми; субъект права на обжалование решения; срок исковой давности обжалования решения общего собрания; способ зашитъ корпоративнъгх прав.

\section{Постановка проблеми}

Загальні збори учасників $є$ вищим органом управління господарського товариства, що має право ухвалювати рішення 3 усіх питань діяльності товариства, у тому числі і з тих, що належать до компетенції інших органів товариства. Цей орган має широкий вплив не лише на функціонування та здійснення діяльності самого товариства, а й вирішує питання здійснення корпоративних прав та інтересів його учасників (акціонерів). Ось чому оскарження рішення загальних зборів господарського товариства $є$ основним способом захисту від порушень прав учасників товариства та від негативних наслідків для існування юридичної особи, що можуть виникнути внаслідок неправомірних рішень загальних зборів. Як свідчить судова практика, серед усіх корпоративних спорів найбільшу частину складають саме спори про визнання рішень загальних зборів товариства недійсними. Така ситуація спричинена відсутністю у законі чітко прописаних підстав визнання рішень загальних зборів товариства недійсними, що $є$ значною прогалиною національного законодавства. Крім того, неоднозначною $є$ ситуація із визначенням кола суб'єктів, які мають право на оскарження рішення загальних зборів господарського товариства. Таким чином, єдиними джерелами правового регулювання окремих питань визнання рішення загальних зборів товариства недійсним є положення Постанови Пленуму Вищого господарсько- 


\section{Цивільне, підприсмницьке, господарське та трудове право}

го суду України «Про деякі питання практики вирішення спорів, що виникають з корпоративних правовідносин» від 25.02.2016 № 4 [1] та напрацьована судова практика. Таким чином, актуальним питанням є встановлення підстав для визнання недійсними рішень загальних зборів та суб'єктів, що мають право на таке оскарження у Законах України «Про акціонерні товариства» та «Про товариства 3 обмеженою та додатковою відповідальністю» задля ефективного захисту порушених прав учасників (акціонерів) господарського товариства і формування єдиної практики вирішення таких корпоративних спорів судами.

Ступінь наукової розробки проблеми

Дослідження окремих питань щодо визнання недійсними рішень загальних зборів учасників товариства проводили у своїх працях В.В. Васильєва, О. М. Вінник, Н. С. Глусь, Ю. М. Жорнокуй, О.Р. Кібенко, Н. А. Сліпенчук, А. В. Сороченко, I. В. Спасибо-Фатєєва, О. В. Щербина, В.А. Яроцький та інші. Проте проблематика визначення конкретних підстав, суб'єктів та строків оскарження рішень загальних зборів потребує подальшого дослідження та вдосконалення, адже розглядається, переважно, фрагментарно разом із іншими елементами захисту порушених корпоративних прав.

Метою цієї статті є обгрунтування положення щодо удосконалення законодавства про процедуру оскарження рішень загальних зборів господарського товариства, а саме: уточнення підстав визнання рішення недійсним; встановлення відповідного строку позовної давності оскарження рішення загальних зборів та суб'єктів права на таке оскарження.

\section{Виклад основного матеріалу}

Серед усіх корпоративних спорів найбільшу частину складають саме спори про визнання загальних зборів товариства недійсними. Судова практика із цього приводу є неоднозначна та суперечлива, внаслідок чого виникають ситуації, коли при аналогічних обставинах приймаються кардинально різні судові рішення. Така ситуа- ція спричинена відсутністю в законодавстві чітко визначених підстав визнання загальних зборів товариства недійсними. Враховуючи це, суди під час розгляду справ щодо визнання рішення загальних зборів товариства недійсними зазвичай керуються узагальненою судовою практикою та Постановою Пленуму Вищого господарського суду України «Про деякі питання практики вирішення спорів, що виникають 3 корпоративних правовідносин» від 25.02.2016 № 4 .

Для визначення таких підстав потрібно з'ясувати правову природу рішення загальних зборів, щодо якої як у вітчизняній теорії, так і в судовій практиці усталеним є підхід віднесення цих рішень до індивідуальних актів, а не до правочинів. Так,А. В. Зеліско зазначає, що акти органів управління юридичної особи не є правочинами, адже вони спрямовані на управління юридичною особою; базуються на волевиявленні кваліфікованої або простої більшості учасників, а значить, не потребують волевиявлення всіх учасників; вони не спричиняють самі по собі цивільно-правові наслідки, так як останні можуть виникати лише на основі взаємодії актів органів управління відповідно до встановленої законом та установчими документами компетенції. Таким чином, рішення загальних зборів за своєю правовою природою є особливим юридичним актом, а тому не може виступати як самостійнийо юридичний факт, який спричиняє виникнення, зміну чи припинення цивільних прав та обов'язків підприємницької юридичної особи приватного права як самостійний суб'єкт цивільних правовідносин [2, с. 77]. До того ж, вивчення судової практики розгляду справ про визнання недійсними рішень загальних зборів юридичної особи підтвердило, що судді КГС ВС додержуються єдиного розуміння правової природи таких рішень як актів ненормативного характеру, а не правочинів [3, с. 101-102].

Так, у Постановах КГС ВС від 10.05.2018 р. у справі 909/597/17, від 19.06.2018 р. у справі №905/1833/17, від 17.07.2018 р. у справі №916/2386/17 зазначається, що рішення загальних зборів учасників (акціонерів, членів) та інших органів юридичної осо- 
би не $є$ правочинами у розумінні статті 202 Цивільного кодексу України (далі - ЦК України) [4]. До цих рішень не можуть застосовуватися положення статей 203 та 215 ЦК України, які встановлюють підстави недійсності правочину, і, відповідно, правові наслідки недійсності правочину за статтею 216 ЦК України. Зазначені рішення $є$ актами ненормативного характеру (індивідуальними актами), тобто офіційними письмовими документами, що спричиняють певні правові наслідки, які спрямовані на регулювання господарських відносин і мають обов’язковий характер для суб'єктів цих відносин.

Таким чином, суд обгрунтував необхідність встановлення окремого чіткого переліку підстав для визнання загальних зборів недійсними. У своїй практиці суди визначають наступні підстави для визнання недійсними рішень загальних зборів учасників (акціонерів, членів) юридичної особи, а саме: невідповідність рішень загальних зборів нормам законодавства (Постанова КГС ВС від 18.04.2018 р. №912/2562/16); порушення вимог закону та/або установчих документів під час скликання та проведення загальних зборів (Постанова КГС ВС від 17.07.2018 р. №910/19401/17); позбавлення учасника (акціонера) можливості взяти участь у загальних зборах (Постанова КГС ВС від 11.09.2018 р. №911/3872/17); прийняття загальними зборами рішень 3 питань, не включених до порядку денного, на розгляд яких не було отримано згоди всіх присутніх на загальних зборах (Постанова КГС ВС від 23.05.2018 р. №914/1567/17); прийняття загальними зборами рішень 3 питань, не включених до порядку денного загальних зборів товариства; відсутність протоколу загальних зборів.

Утім слід зазначити, що під час вивчення практики розгляду КГС ВС спорів про визнання недійсним рішення загальних зборів учасників (акціонерів, членів) юридичної особи було встановлено, що часом особи, які звертаються 3 таким позовом, неправильно оцінюють наявність прав, що можуть бути захищені таким способом. Так, у постанові від 02.05.2018 у справі№ 912/779/17 КГС ВС зауважив, що недо- тримання вимог закону та установчих документів юридичної особи під час скликання і проведення загальних зборів не може визнаватися порушенням прав тих позивачів, які не $є$ учасниками (акціонерами, членами) цієї особи [5]. Також Постанова Пленуму ВГСУ «Про деякі питання практики вирішення спорів, що виникають 3 корпоративних правовідносин» від 25.02.2016№ 4 зауважує, що господарським процесуальним законодавством не передбачено можливості звернення до господарського суду зі скаргою на дії або бездіяльність органів управління юридичних осіб. Проте, особу, чиї права порушено діями або бездіяльністю органу управління юридичної особи, не позбавлено права на звернення до суду з позовом про зобов'язання юридичної особи вчинити певні дії або утриматись від вчинення таких дій. Окрім цього, у законодавстві неможливо визначити всі підстави, які спричинятимуть використання такого способу захисту, як визнання недійсними рішень органів управління господарського товариства. До того ж, у разі порушення права на участь учасника в управлінні товариством можна використати й інший спосіб захисту, як, наприклад, вимагати від акціонерного товариства здійснення обов'язкового викупу належних йому акцій (ст. 68 Закону України «Про акціонерні товариства») [6] або спонукати акціонера до реалізації належного йому права на управління акціонерним товариством шляхом участі в загальних чи позачергових зборах товариства (ч. 1 ст. 29 Закону України «Про акціонерні товариства») [7, с. 64-65]. Тобто учасник (акціонер) може обрати й інший спосіб захисту порушеного права.

Отже, вивчення судової практики розгляду спорів про визнання недійсним рішення загальних зборів учасників (акціонерів) господарського товариства свідчить, що не всі порушення законодавства, допущені під час скликання та проведення загальних зборів, є підставами для визнання недійсними прийнятих ними рішень.

Варто зазначити, що із прийняттям нового Закону України «Про товариства 3 обмеженою та додатковою відповідальністю» [8] та після внесення змін до Закону 


\section{Цивільне, підприсмницьке, господарське та трудове право}

України «Про акціонерні товариства» деякі положення Постанови Пленуму Вищого господарського суду України «Про деякі питання практики вирішення спорів, що виникають 3 корпоративних правовідносин» від 25.02.2016 № 4 вже втратили свою актуальність і не можуть бути застосовані задля визначення підстав для визнання загальних зборів недійсними. Як приклад можна зазначити таку підставу, як прийняття загальними зборами рішення учасників за відсутності кворуму для проведення загальних зборів чи прийняття рішення або у разі неможливості встановлення наявності кворуму, оскільки така підстава вже не може бути застосована до товариства 3 обмеженою відповідальністю, адже новий закон не потребує встановлення кворуму зборів товариства. Новий законодавчий підхід передбачає, що кількість голосів рахується не від присутніх на загальних зборах, а від усієї кількості учасників товариства в цілому. У такий спосіб, як слушно зауважив Р.С. Аукашов, вирішено питання «недобросовісної неявки», внаслідок якої блокувалась будь-яка можливість для проведення загальних зборів [9, с. 110-111]. Відтепер відсутність кворуму як формальне порушення не є підставою визнання загальних зборів учасників господарського товариства такими, що не відбулись. Крім того, не є безумовною підставою для визнання рішення загальних зборів учасників недійсним - прийняття рішень 3 питань, не включених до порядку денного, на розгляд яких не було отримано згоди всіх присутніх на загальних зборах, адже таке рішення може становити елемент вирішення іншого питання, включеного до порядку денного, тому тут потрібно враховувати цю підставу залежно від конкретного випадку. Також не $є$ цілком очевидною для суду й підстава щодо відсутності протоколу загальних зборів товариства 3 обмеженою відповідальністю, про що свідчить справа про вимогу товариства про повернення сплати учасникам дивідендів як безпідставно отриманих.

Крім цього, немає потреби ділити підстави визнання рішень загальних зборів недійсними на загальні та безумовні, адже суди мають у кожному конкретному ви- падку встановлювати факт порушення цим рішенням прав та законних інтересів учасника (акціонера) товариства та при цьому враховувати, яким чином ці порушення впливають на прийняття загальними зборами відповідного рішення. 3 приводу цього, Касаційний господарський суд підкреслює [10], що формальна незгода учасника юридичної особи 3 прийнятим загальними зборами рішенням не може бути підставою для визнання його недійсним. Тобто обов'язковою умовою для визнання рішення загальних зборів недійсним є доведення факту порушення таким рішенням прав та законних інтересів позивача. Саме тому відсутня необхідність розмежовувати підстави на загальні та безумовні.

Таким чином, на підставі викладеного представляється доцільним визначити конкретні підстави визнання недійсними рішень загальних зборів учасників (акціонерів) та ввести ці положення до Законів України «Про товариства 3 обмеженою та додатковою відповідальністю», «Про акціонерні товариства»:

1) прийняття загальними зборами рішення за відсутності кворуму для проведення загальних зборів або у разі неможливості встановлення наявності кворуму (окрім товариства 3 обмеженою відповідальністю);

2) порушення вимог закону та/або установчих документів під час скликання та проведення загальних зборів;

3) прийняття загальними зборами рішень $з$ питань, не включених до порядку денного загальних зборів товариства;

4) відсутність протоколу загальних зборів товариства, підписаного головою і ceкретарем зборів;

5) позбавлення учасника (акціонера) можливості взяти участь у загальних збоpax;

6) невідповідність рішень загальних зборів нормам законодавства.

На практиці це допоможе розвантажити господарські суди від надмірної кількості безпідставних позовів про визнання недійсними рішень загальних зборів, виробити однорідну судову практику 3 цього питання, гарантувати ефективний захист 
корпоративних прав учасників (акціонерів) товариств, а також забезпечить правову визначеність загалом. Окрім цього, встановлення в законодавстві таких норм унеможливить зловживання своїми правами як учасниками (акціонерами) товариства, так і загальними зборами товариства.

Крім того, й досі як у науковій літературі, так і на практиці залишається дискусійним питання визначення кола суб'єктів, які мають право на оскарження рішення загальних зборів учасників господарського товариства. Так, одні науковці вважають, що потрібно обмежити коло таких осіб лише випадками, коли акціонер не брав участі у голосуванні або голосував проти такого рішення, та його права і (або) законні інтереси, таким чином, були порушені [11, c. 23]. Інші автори, навпаки, зазначають, що таке обмеження є недоцільним, адже у певних випадках порушення прав (інтересів) акціонера не залежить від його участі у голосуванні та від того, чи голосував він «за» або «проти» ухваленого рішення [12,c. 93].

У свою чергу, судова практика виробила підхід, згідно з яким у разі належного повідомлення учасника про скликання загальних зборів, його неявка та неучасть у голосуванні не може бути підставою для визнання недійсним рішення загальних зборів. Підтвердженням цього може бути Постанова Верховного Суду від 16.05.2018 у справі №910/21025/16, у якій суд, враховуючи всі обставини справи, встановив, що неявка належно повідомленого учасника на загальні збори не є підставою для визнання недійсним рішення, оскільки, достовірно знаючи про проведення таких загальних зборів, маючи намір реалізувати своє корпоративне право на управління справами товариства з обмеженою відповідальністю, участь позивача у загальних зборах залежала тільки від його суб'єктивного бажання та вчинення відповідних дій 3 метою його реалізації [13]. Отже, представляється необхідним передбачити в чинному законодавстві перелік суб'єктів, які матимуть право на оскарження рішення загальних зборів учасників (акціонерів), враховуючи напрацьовану практику законодавства інших країн, зокрема вже випробуваний часом ефективний досвід Німеччини, де Закон «Про акціонерні товариства» [14, с. 105] містить окрему статтю 245, яка наводить чіткий перелік суб'єктів, що мають право на оскарження рішення загальних зборів: 1) акціонер, який був присутній на загальних зборах, якщо він голосував проти рішення загальних зборів; 2) акціонер, який не брав участі у загальних зборах, якщо він неправомірно не був допущений на них, або якщо загальні збори були скликані неналежним чином, або якщо питання, 3 якого ухвалювалося рішення, не було належним чином опубліковане; 3) кожний акціонер, якщо інший акціонер, здійснюючи право голосу, намагався на шкоду товариству чи його акціонерам набути для себе чи третьої особи особливі вигоди, а рішення сприяло цій меті, за винятком випадків, коли таке рішення надає компенсацію акціонерам за збитки.

Також ще одним проблемним питанням залишається визначення оптимального строку для оскарження рішення загальних зборів товариства з обмеженою відповідальністю, адже зазначена у статті 258 ЦК України спеціальна позовна давність в один рік є занадто довгою, чим створює передумови для зловживань правом оскарження рішення загальних зборів шляхом подання учасниками позовів до суду 3 метою блокування важливих рішень товариства, що спричинятиме загрозу його нормальному функціонуванню. Варто зазначити, що широкі можливості щодо оскарження рішень загальних зборів, надані учасникам, часто стають не засобом встановлення балансу інтересів і припинення порушень 3 боку товариства, а інструментом для махінацій чи знаряддям шантажу в руках недобросовісних учасників корпоративних правовідносин. Це відбувається таким чином, що учасники подають такі позови до суду, незалежно від наявності підстав для цього, i за припинення судового процесу пропонують іншим учасникам або посадовим особам господарського товариства заплатити їм викуп. Таким чином, такі учасники можуть блокувати діяльність товариства та тиснути на його посадових осіб, що може 


\section{Цивільне, підприсмницьке, господарське та трудове право}

призвести до порушення або й припинення діяльності такого товариства. За кордоном законодавець захищає юридичну особу від недобросовісних оскаржень шляхом встановлення скорочених строків позовної давності для цієї категорії корпоративних спорів. Як приклад, вищезазначений Закон Німеччини «Про акціонерні товариства», а саме ст. 246, взагалі передбачає строк оскарження в один місяць 3 дня ухвали рішення загальних зборів [14, с.105].В Україні було $б$ доцільно привести строк для оскарження рішень загальних зборів товариства з обмеженою відповідальністю у відповідність із уже встановленим для акціонерного товариства у ст. 50 Закону України «Про акціонерні товариства» строком у три місяці 3 дати його прийняття. Цей строк вже випробуваний часом i містить необхідні пристосовані до вітчизняного законодавства мінімальні часові межі для захисту своїх корпоративних прав без можливості щодо загрози нормальному функціонуванню господарського товариства. 3 огляду на це, для товариства з обмеженою відповідальністю необхідно встановити такий самий строк для оскарження рішення загальних зборів, як і для акціонерного товариства - у три місяці з дати його прийняття.

\section{Висновки}

Для забезпечення ефективного захисту корпоративних прав учасників (акціонерів) товариств, захисту самого суб'єкта господарювання - господарського товариства від зловживань правами учасниками (акціонерами) та для правової визначеності загалом, необхідно в перспективному законодавстві, по-перше, визначити перелік підстав для визнання недійсними рішень загальних зборів; по-друге, уточнити коло суб'єктів, які мають право на оскарження рішень загальних зборів, а саме: 1) учасник (акціонер), який був присутній на загальних зборах, якщо він голосував проти рішення загальних зборів; 2) учасник (акціонер), який не брав участі у загальних зборах, якщо він неправомірно не був допущений на них, або якщо загальні збори були скликані неналежним чином, або якщо питання, 3 якого ухвалювалося рішення, не було належним чином опубліковане; 3) кожний учасник (акціонер), якщо інший учасник (акціонер), здійснюючи право голосу, намагався на шкоду товариству чи його учасникам (акціонерам) набути для себе чи третьої особи особливі вигоди, а рішення сприяло цій меті, за винятком випадків, коли таке рішення надає компенсацію учасникам (акціонерам) за збитки; та, по-третє, встановити строк оскарження рішення загальних зборів - три місяці - для учасників товариств 3 обмеженою відповідальністю.

Практична значимість зазначених положень сприятиме удосконаленню законодавства 3 питань оскарження рішень загальних зборів господарських товариств, усуненню застарілих норм, формуванню стабільної судової практики під час розгляду цього виду корпоративних спорів, зменшенню кількості безпідставних позовів щодо визнання загальних зборів недійсними. Крім того, ці пропозиції допоможуть запобігти пред'явленню позовів несумлінними позивачами, протидіяти та усунути можливі зловживання правом на оскарження рішень загальних зборів, а також забезпечать захист законних прав та інтересів одночасно як учасників (акціонерів), так і самого господарського товариства від правопорушень.

\section{Література}

1. Про деякі питання практики вирішення спорів, що виникають 3 корпоративних правовідносин: Постанова Пленуму Вищого господарського суду України № 4 від 25.02.2016. URL: https://zakon.rada.gov. ua/laws/show/v0004600-16\#Text (дата звернення: 25.05.2021).

2. Зеліско А.В. Юридичні акти як форма реалізації правосуб'єктності підприємницьких юридичних осіб приватного права. Актуальні проблеми вдосконалення чинного законодавства Украӥни. 2016. №42. С. 70-83.

3. Корпоративні спори: коментар судової практики / I. В. Спасибо-Фатєева,В.І. Крат, Н. Ю. Філатова та ін. ; за заг. ред. І. В. Спасибо-Фатєєвої. Харків: Право, 2018. 288 c. 
4. Цивільний кодекс України: Закон України від 16 січня 2003 р. № 435-IV.Відомості Верховної Ради Украӥни. 2003.№№ 40-44. Ст.356.

5. Постанова Верховного Суду від 02.05.2018 у справі № 912/779/17. URL: https://reyestr.court.gov.ua/Review/73840069 (дата звернення: 25.05.2021).

6. Про акціонерні товариства: Закон України від 17.09.2008 р. № 514-VI. Відомості Верховної Ради України. 2008. № 50-51. ст.384.

7. Галіян I. Визнання недійсними рішень органів управління господарським товариством як спосіб захисту корпоративних прав. Підприємництво, господарство $i$ право. 2020. №5. С. 63-68.

8. Про товариства з обмеженою та додатковою відповідальністю: Закон України від 06.02.2018 р. № 2275-VIII. Відомості Верховної Ради. 2018. № 13. ст.69.

9. Аукашов Р.С. Товариства 3 обмеженою та додатковою відповідальністю як суб“єкти цивільного права: дис. ...канд. юрид. наук: 12.00.03 «Цивільне право і цивільний процес». Тернопіль, 2020. 223 с.

10. Постанова Верховного Суду від 25.09.2019 р. у справі №910/10932/18. URL: https://reyestr.court.gov.ua/Review/84525190 (дата звернення: 26.05.2021).

11. Спасибо-Фатєева I. В. Цивільноправові проблеми акціонерних правовідносин : автореф. дис. ... д-ра юрид. наук: 12.00.03. Харків, 2000. 36 с.

12. Щербина О. В. Правове становище акціонерів за законодавством України. Київ: ЮрінкомІнтер, 2001. 158 с.

13. Постанова Верховного Суду від 16.05.2018 у справі №910/21025/16. URL: https://reyestr.court.gov.ua/Review/74478791 (дата звернення: 27.05.2021).

14. Сливінська А.В. Проблеми визнання недійсними рішень загальних зборів господарських товариств. Правова держава. 2018. №32. C. 101-110.

\section{References}

1. Resolution of the Plenum of the $\mathrm{Su}$ preme Economic Court of Ukraine On Some Issues of Dispute Resolution Practice Arising from Corporate Legal Relations, № 4,
25.02.2016. Available at: https://zakon.rada. gov.ua/laws/show/v0004600-16\#Text_[Accessed 25.05.2021].

2. Zelisko, A.V., 2016. Yurydychni akty yak forma realizatsii pravosubiektnosti pidpryiemnytskykh yurydychnykh osib pryvatnoho prava. [The legal acts as form of realization of the legal personality of the entrepreneurial legal entities of Private Law]. Aktualni problemy vdoskonalennia chynnoho zakonodavstva Ukrainy, issue 42, pp. 70-83.

3. Spasybo-Fatieieva, I. V., Krat, V.I., Filatova, N.Iu. and others, 2018. Korporatyoni spory: komentar sudovoi praktyky [Corporate disputes: a commentary on case law]. Kharkiv: Pravo.

4. The Civil Code of Ukraine 2003. Vidomosti Verkhovnoi Rady Ukrainy, №№4044. pp.356.

5. The decision of the Supreme Court of 02.05.2018 in the case № 912/779/17. Available at: https://reyestr.court.gov.ua/ Review/73840069 [Accessed 25.05.2021].

6. Law of Ukraine On Joint Stock Companies 2008. Vidomosti Verkhovnoi Rady Ukrainy, №50-51. pp.384.

7. Haliian, I., 2020. Vyznannia nediisnymy rishen orhaniv upravlinnia hospodarskym tovarystvom yak sposib zakhystu korporatyvnykh prav. [Invalidation of decisions of management bodies of a company as a way to protect corporate rights]. Pidpryiemnytstvo, hospodarstvo i pravo, issue 5, pp. 63-68.

8. Law of Ukraine On Limited and Additional Liability Companies 2018. Vidomosti Verkhovnoi Rady Ukrainy, № 13. pp.69.

9. Lukashov, R.S., 2020. Limited liability and additional liability companies as subjects of civil law. Ph.D.Dissertation. Ternopil National Economic University.

10. Resolution of the Supreme Court of September 25, 2019 in case №910/10932/18. Available at: https://reyestr.court.gov.ua/ Review/84525190 [Accessed 26.05.2021].

11. Spasybo-Fatieieva, I. V., 2000. Civil law problems of joint-stock legal relations. Abstract of the D.Sc. Dissertation. Kharkiv.

12. Shcherbyna, O. V., 2011. Pravove stanovyshche aktsioneriv za zakonodavstvom Ukrainy [Legal status of shareholders under 


\section{Цивільне, підприсмницьке, господарське та трудове право}

the legislation of Ukraine]. Kyiv: YurinkomInter.

13. Resolution of the Supreme Court of 16.05.2018 in case №910 / 21025/16. Available at: https://reyestr.court.gov.ua/ Review/74478791 [Accessed 27.05.2021].

14. Slyvinska, A.V.,2018. Problemy vyznannia nediisnymy rishen zahalnykh zboriv hospodarskykh tovarystv. [Problems of the invalidation of resolutions of the general meetings]. Pravova derzhava, issue 32, pp. 101-110.

\section{Казакова K.I. ДЕЯКІ АСПЕКТИ ВИЗНАННЯ РІШЕНЬ ЗАГАЛЬНИХ ЗБОРІВ ГОСПОДАРСЬКИХ ТОВАРИСТВ НЕДІЙСНИМИ}

Темою иієї статті є проблемні питання застосування такого способу захисту корпоративних прав, як визнання недійсними рішень загальних зборів господарсъкого товариства. Метою иъого дослідження є обгрунтування положення щодо удосконалення законодавства про процедуру оскарження рішень загальних зборів господарсъкого товариства, а саме: уточнення підстав визнання рішення недійсним; встановлення відповідного строку позовної давності оскарження рішення загальних зборів та суб'єктів права на таке оскарження. Для вирішення завдання наукового дослідження були застосовані формальнологічний, логіко-юридичний, порівняльно-правовий та структурно-функціональний методи.У результаті изього дослідження було: обгрунтовано необхідність встановлення окремого чіткого переліку підстав для визнання загальних зборів недійсними; з'ясовано правову природу рішення загальних зборів господарсъкого товариства; проаналізовано судову практику щодо розгляду спорів про визнання недійсним рішення загальних зборів учасників (акиіонерів, членів) юридичної особи; з'ясовані застарілі положення Постанови Пленуму Вищого господарсъкого суду Украӥни «Про деякі питання практики вирішення спорів, що виникають з корпоративних правовідносин» від 25.02.2016 № 4 у зв'язку із прийняттям нового Закону України «Про товариства з обмеженою та додатковою відповідальністю» та після внесення змін до Закону Украӥни «Про акціонерні товариства»; запропоновано скасувати поділ під- став визнання рішень загальних зборів недійсними на загальні та безумовні; визначено перелік підстав визнання недійсними рішень загальних зборів; уточнено коло суб'єктів, які мають право на оскарження рішень загальних зборів; аргументовано встановлення для учасників товариства 3 обмеженою відповідальністю такого самого строку оскарження рішення загальних зборів, як $і$ для акиіонерів акиіонерного товариства - у три місячі з дати його прийняття; визначено практичну значимість встановлення у Законах України «Про товариства з обмеженою та додатковою відповідальністю» та «Про акиіонерні товариства» конкретних підстав визнання недійсними рішень загальних зборів, чіткого кола осіб, які мають право на таке оскарження, а також строк, протягом якого така особа може здійснити своє право на оскарження.

Ключові слова: загальні збори товариства; рішення загальних зборів товариства; оскарження рішень загальних зборів товариства; підстави визнання рішень загальних зборів недійсними; суб'єкт права на оскарження рішення; строк позовної давності оскарження рішення загальних зборів; спосіб захисту корпоративних прав.

\section{Kazakova K.I. \\ SOME ASPECTS OF INVALIDATION OF DEGISIONS OF THE GENERAL MEETING OF THE COMPANY}

The topic of this article is the problematic issues of application of such a method of protection of corporate rights as invalidation of decisions of the general meeting of the company. The purpose of this study is to substantiate the provisions on improving the legislation on the procedure for appealing the decisions of the general meeting of the company, namely: clarification of the grounds for invalidation of the decision; establishing the appropriate statute of limitations for appealing the decision of the general meeting and the subjects of the right to such an appeal. To solve the problem of scientific research, formal-logical, logicallegal, comparative-legal and structural-functional methods were used. As a result of this study it was: substantiated the need to establish a separate clear list of grounds for recognizing the general meeting invalid; the legal nature of the decision of the general meeting of the company is clarified; the court practice on consideration of disputes on invalidation of the decision of the general meeting of participants (shareholders, members) of the legal entity is analyzed; outdated 


\section{АНОТАЦІЯ}

у изй статті досліджено проблемні питання застосування такого способу захисту корпоративних прав, як визнання недійсними рішень загальних зборів господарсъкого товариства. Обгрунтовано необхідність встановлення окремого чіткого переліку підстав для визнання загальних зборів недійсними. 3'ясовані застарілі положення Постанови Пленуму Вищого господарсъкого суду Украӥни «Про деякі питання практики вирішення спорів, що виникають з корпоративних правовідносин» від 25.02.2016 № 4 у зв'язку із прийняттям нового Закону України «Про товариства з обмеженою та додатковою відповідальністю» та після внесення змін до Закону Украӥни «Про акціонерні товариства». Визначено перелік підстав визнання недійсними рішень загальних зборів. Уточнено коло суб’єктів, які мають право на оскарження рішень загальних зборів; аргументовано встановлення для учасників товариства з обмеженою відповідальністю такого самого строку оскарження рішення загальних зборів, як $і$ для акиіонерів акиіонерного товариства - у три місячі з дати його прийняття.

Ключові слова: загальні збори товариства; рішення загальних зборів товариства; оскарження рішень загальних зборів товариства; підстави визнання рішення загальних зборів недійсними; суб'єкт права на оскарження рішення; строк позовной давності оскарження рішення загальних зборів; спосіб захисту корпоративних прав. provisions of the Resolution of the Plenum of the Supreme Economic Court of Ukraine "On some issues of dispute resolution arising from corporate relations" from 25.02.2016 № 4 in connection with the adoption of the new Law of Ukraine "On Limited and Additional Liability Companies" and after amendments to the Law of Ukraine "On Joint Stock Companies"; it is proposed to abolish the division of the grounds for recognizing the decisions of the general meeting as invalid into general and unconditional; the list of the bases of recognition of invalid decisions of general meeting is defined; the range of subjects that have the right to appeal the decisions of the general meeting is specified; the establishment of the same term for appealing the decision of the general meeting as for the shareholders of the joint-stock company - within three months from the date of its adoption - is substantiated for the participants of the limited liability company; the practical significance of establishing in the Laws of Ukraine "On Limited and Additional Liability Companies" and "On Joint Stock Companies" specific grounds for invalidating the decisions of the general meeting, a clear range of persons entitled to such an appeal, as well as the period during which such a person may exercise your right to appeal.

Keywords: general meeting of the company; decisions of the general meeting of the company; appeal against the decisions of the general meeting of the company; grounds for recognizing the decisions of the general meeting as invalid; the subject of the right to appeal the decision; the statute of limitations for appealing the decision of the general meeting; way to protect corporate rights. 